\title{
1 \\ Editorial Introduction: Living in Dangerous Times - Fear, Insecurity, Risk and Social Policy
}

David Denney

Insecurity, fear and risk have come to dominate individual and collective consciousness in the twenty-first century. Although global insecurity has been created by terrorism, pollution, global epidemics and famine, risks have also come to be defined with respect to more mundane aspects of everyday life. Seemingly innocuous objects including carpets, footwear, televisions, vacuum cleaners, personal stereos, mobile phones and even tea cosies are often associated with potential risk (Spicker 200r; Denney 2005).

Some events, however, have come to symbolise global insecurity. The claim that the global crisis in the banking system and September inth 'changed the world forever' can be challenged. A sense of global fear existed before the collapse of the World Trade Center in 200I. A global economic depression had occurred previously, during the inter-war period. Government and the media present many aspects of public life including the supply of basic services as being under threat. Since $9 /$ I risk stories have been created around possible dangers to transportation systems, fuel, food and water supply, banking and financial systems, defence infrastructure and government itself. The impact of global warming on climate change adds to the fear of imminent mass destruction.

This volume examines how far such aggressively defensive thinking can be seen in aspects of social policy development. The nature of protection and security provided by the state has changed since the Second World War. Following Beveridge in the UK, state-funded systems were created to cushion the impact of ill health and poverty during the postwar period. The creation of the welfare state in other developed countries characterized a state sponsored approach to individual risk management. The state, individuals and their employers paid for social insurance against adversity.

In 2005 in his Dimbleby lecture, the then Metropolitan Police Commissioner Sir Ian Blair, alluding to Beveridge, described personal insecurity as the sixth great evil, along with idleness, ignorance, squalor, disease, and want (BBC 2005). Anthony Giddens, who helped guide the New Labour project, has argued for policies which develop independence and individual potential. 
However, no specific suggestions are made as to how those who cannot grasp opportunities presented in the risk society can be best assisted by either the state or the private sector working together or separately. Many people feel ambivalent about risk and uncertainty and are often unable to differentiate between the progress that they experience in living standards and other pressures they feel in social life. Those at most risk from social change may see greater flexibility in society as a threat rather than an opportunity (Taylor-Gooby 2000).

Attention to risk control in social policy appears to reflect operational practices in the civil aviation industry. At airports all passengers are routinely screened to ensure that they do not pose a risk to the safety of the general public. The onus is on the passenger to prove innocence. Psychological profiling exercises, some covert, are being developed to identify risky passengers. Hand luggage is X-rayed and at some international airports every fifth passenger will have hand baggage manually examined. Once aboard videos relating to life rafts, life jackets, emergency chutes and exits are shown as passengers contemplate the consumption of their duty-free highly flammable alcohol.

Social welfare claimants and service users are treated as being potentially undeserving burdens on already overstretched social care budgets until they can prove the contrary. Needs assessments and the delivery of packages of care are designed to ensure that public funds are regulated, and that individuals draw upon their own financial and human resources before becoming dependent on the state. The use of risk assessment stretches beyond the provision of welfare. In the criminal justice system possible candidates for community sentences are assessed though a national offender risk assessment system. As is the case at the airport, service-providing agencies need regulated escape routes in a world in which the word 'accident' is becoming unacceptable. Risk regulation mechanisms provide the framework for the equivalent of seat belts, life jackets and X-ray machines in the formulation of policy.

The contributors to this volume are drawn from a wide variety of academic disciplines reflecting the multidisciplinary approach. Two central themes run through the contributions. Firstly, policies are built around the idea of public resilience, whilst simultaneously promoting notions of public vulnerability. Furedi analyses the tendency for policy-makers to 'recycle' the paradigm of vulnerability. Littlechild develops the theme of vulnerability and resilience in his analysis of the impact of risk assessment in child protection work. Gabe and Elston review zero tolerance of violence perpetrated on health care workers and interpret this in the wider context of risk anxiety and insecurity. Atkinson analyses fear and insecurity in hidden spaces inhabited by 'problem' people. Quilgars, Jones and Abbott present new research designed to investigate whether social and cultural differences along the dimensions of disability, sexuality, faith and ethnicity influence attitudes to financial risk and insecurity. Kemshall and Wood explore critical factors in the trend towards public protection and the framing of risk and risky offenders.

Secondly, the perceived erosion of social securities gives rise to policies which promote social exclusivity and the strengthening of boundaries, often at the expense of human rights. Denney examines the complex policy interplay 
between fear, human rights and New Labour's approach to risk. The 'precautionary principle' has come to dominate specific areas of both domestic social and foreign policy. Delanty argues that fear of others and anxieties about the future have resulted in a crisis of European solidarity and a wider crisis of collective purpose. The European project, he claims, must give more attention to social justice and inclusive forms of social solidarity in order to combat such developments. Rumford argues that fear has become central to social scientific understandings of insecurities and focuses on the means by which the world is rendered strange. Rumford goes on to analyse how uncertainty, unpredictability and insecurity can open up new forms of governance. Denney argues that both foreign and social policy have been driven by a precautionary logic which has in some cases compromised human rights and due process. Greve in his conclusion to this volume asks how possible it is for the welfare state to make a 'rational' response to 'new risks'.

All these chapters address critical contemporary questions for policy-makers and policy analysts. To what extent has a burgeoning epidemic of fear exacerbated by $9 /$ i I and subsequent global acts of terrorism created a new impetus for reactive risk-centred social policy development? How far has due process in law and human rights become secondary to the endless regulated search for security and safety? To what extent does the policy backdrop of danger serve to increase social division?

\section{References}

BBC (2005), Dimbleby Lecture, Sir Ian Blair, I6th November Available on BBC

News Channel: http://news.bbc.co.uk

Denney, D. (2005), Risk and Society, London: Sage.

Giddens, A. (2000), The Third Way and its Critics, Cambridge: Polity Press.

Jordan, B. (1998), The New Politics of Welfare, London: Sage.

Spicker, P. (200I), Social Insecurity and Social Protection, in Edwards, R. and Glover, J. (eds) Risk and Citizenship, London: Routledge.

Taylor-Gooby, P. (2000), Risk, Trust and Welfare, London: Macmillan. 